\title{
Preparation and Properties of the Fe/N co-doped Graphene Composite Materials
}

\author{
Yanbo Li, Ye Wan* , Haixiao Zhang, Xiaodan Wang \\ School of Materials Science and Engineering, Shenyang Jianzhu University, Shenyang 110168, China \\ *E-mail: ywan@sjzu.edu.cn
}

doi: $10.20964 / 2021.04 .33$

Received: 5 December 2020 / Accepted: 5 February 2021 / Published: 28 February 2021

\begin{abstract}
The $\mathrm{Fe}$ doped and the $\mathrm{Fe} / \mathrm{N}$ co-doped graphene composite materials were prepared from a graphene oxide dispersion by a hydrothermal method. $\mathrm{Fe}^{2+}$ was oxidized to be $\alpha-\mathrm{Fe}_{2} \mathrm{O}_{3}$, while graphene oxide was reduced to be reduced graphene oxide ( $\mathrm{rGO}$ ) during the hydrothermal reaction. For the Fe/ $\mathrm{N}$ co-doped grapheme composite material, nitrogen atoms were incorporated into the graphene structures in the form of $\mathrm{C}-\mathrm{N}$ and $\mathrm{C}=\mathrm{N}$ bonds. Both of the $\mathrm{Fe}$ doped and the $\mathrm{Fe} / \mathrm{N}$ co-doped graphene composite materials exhibited a 3D hierarchical porous frame and a large surface area, which facilitated ion and electron transport. The results from electrochemical impedance spectroscopy (EIS) shows both of the charge transfer resistance and the diffusion resistance of the $\mathrm{Fe} / \mathrm{N}$ co-doped material are smaller than that of the Fe doped material, which indicated that nitrogen played an important role in improving conductivity, the ion and electron transport kinetics and the redox reaction activity in the Fe/ $\mathrm{N}$ co-doped graphene composites material.
\end{abstract}

Keywords: Reduced graphene oxide; Hydrothermal method; Doping; Iron oxide; EIS

\section{$\underline{\text { FULL TEXT }}$}

(C) 2021 The Authors. Published by ESG (www.electrochemsci.org). This article is an open access article distributed under the terms and conditions of the Creative Commons Attribution license (http://creativecommons.org/licenses/by/4.0/). 